\title{
The examination of pedagogical formation education certificate program students' perceptions regarding education and ideal education through metaphors ${ }^{1}$
}

\author{
Mevlüt Kara, Gaziantep University, mevlutkara85@gmail.com, ORCID: 0000-0002-6381-5288 \\ Emrullah Akcan, Gaziantep University, emrullahakcan@gmail.com, ORCID: 0000-0002-5492-4159
}

\begin{abstract}
The aim of this research is to reveal the perceptions of pedagogical formation certificate program students about education and ideal education concepts through metaphors. In this research, the phenomenology design, one of the qualitative research designs, was used. The study group consisted of 98 pedagogical formation certificate program students studying at Nizip Education Faculty of Gaziantep University in 2018-2019 academic year. The data of the study was collected through a structured interview form prepared by the researchers. The data obtained was transferred to computer media and analyzed by content analysis. The participants presented 69 different metaphors about the concept of education. Among these metaphors; tree, book, life and horse racing metaphors were used the most. Metaphors for the concept of education are grouped under 11 conceptual categories. Eight of these categories have positive features, while three have negative features. 74 different metaphors were put forward by the participants about the ideal education. Among these metaphors; life, sapling, book and playground metaphors were used the most, respectively. Metaphors for the concept of ideal education were gathered under 11 conceptual categories.
\end{abstract}

Keywords: Pedagogical formation, education, ideal education, metaphor.

Received: 11.05 .2020

Accepted: 13.08 .2020

Published: 01.12.2020

\section{INTRODUCTION}

The most important driving force of the social development of the countries is undoubtedly education. Education also serves as a means of transferring the knowledge, culture and other humanities that societies have acquired and developed in the historical process to generations that follow them. Today, in addition to these functions of education, it has become the main objective to train qualified manpower needed by societies and to create an effective citizenship bond among citizens. The main subject of education, which is one of the basic institutions of contemporary societies, is undoubtedly the teacher (Çelikten, Şanal, \& Yeni, 2005). The teacher has a great responsibility in the effective and efficient execution of educational activities carried out in the classrooms. Briefly, the part of the education and training activities that is in the classroom is completely up to the teacher. It can be said that some subjects such as learning outcomes, procurement and use of lesson materials, arrangement of learning environments, determination of methods, techniques and strategies in the delivery of lectures are directly related to the competencies of the teacher. It can be said that as a result of effective implementations of in-class education practices, students will be more successful academically and more advantageous in their personal development.

In Article 43 ${ }^{\text {rd }}$ of the National Education Basic Law No. 1739 dated June 24, 1973, teaching is defined as "a specialized profession that takes on the education, training, and related management duties of the state" and the preparation for teaching profession is described to be "provided by general knowledge, specialization, and pedagogical formation" (Ministry of National Education [MoNE], 1973). As can be understood from this article of law, teaching is a special area of specialization and the Higher Education Institution (HEI) has pointed out that the

\footnotetext{
${ }^{1}$ This research was presented as an oral presentation under the title of "Eğitim Fakültesi Mezunu Olmayan Öğretmen Adaylarının Eğitim Kavramına İlişkin Metaforik Algıları" at the 5th International TURKCESS Education and Social Sciences Congress held in Istanbul between June 27-29 2019.
} 
candidates who will perform this profession should be trained in education faculties. The reason is that, when today's higher education institutions are examined, it is seen that the units which provide general knowledge, specialization, and pedagogical formation training, which are the requirements of the teaching profession, are education faculties. In addition to the education faculties as the main institution for training teachers, in various periods since the 90s, HEI has allowed the students who have graduated from certain faculties other than the education faculties (the Faculty of Arts and Science, the Faculty of Economics and Administrative Sciences, etc.) to become teachers by providing them pedagogical formation training. However, these formation trainings have often been the subject of controversy and in some periods they have been removed and put back into effect. The main subject of these discussions has been whether prospective teachers who are not graduates of the faculty of education can be provided as a competent teacher by giving them a pedagogical formation (Çocuk, Yokuş, \& Tanrıseven, 2015; Ekiz \& Koçyiğit, 2013). It is obvious that with this process studied in various aspects by the field experts, the discussions will gain a more scientific basis. From this point of view, it can be said that the perception of the basic components of the education system by prospective teachers is important and should be examined.

Metaphors have started to be used frequently in educational researches, especially in recent years (Akınoglu, 2017; Akbaba-Altun \& Apaydın, 2013; Aslan, 2013; Aubusson, Harrison, \& Ritchie, 2006; Aydın \& Pehlivan, 2010; Buchanan, 2015; Cerit, 2010; Erden, 2016 ; Goldstein, 2005; Haskins, 1989; Jensen, 2006; Johnson, 2001; Kim, 2012; Koç, 2014; Konopasky \& Reybold, 2015; Küçük \& Yalçın, 2014; Kuyumcu \& Özsarı, 2016; Liaquat \& Naz, 2016; Mouraz , Pereira, \& Monteiro, 2013; Noyes, 2006; Ogurlu, Öpengin, \& Hızl, 2015; Pektaş \& Kıldan, 2009; Saban, 2004; Şahin \& Sabancı, 2018; Tulunay Ateș, 2016; Turan, Yıldırım, \&Tıkman, 2016; Yıldızlı, Erdol, Baştuğ, \& Bayram, 2018). When these researches related to education are examined, it is seen that researches have been carried out for many stakeholders of education such as teachers, students, and school administrators and that the importance of metaphors has been particularly emphasized in such researches. The fact that metaphors make ideas tangible has helped us frequently make use of these concepts. In other words, metaphors reveal the perceptions that many variables related to education such as students, teachers, parents, schools, and school administrators generates in individuals and create an important area of use in raising awareness about the subject (Mahlios, 2002). The frequent use of the concept of metaphor in education is related to the concepts of education and metaphor being essential components of daily life. Because education starts in the family immediately after birth and continues for life. According to Kiral (2015), metaphors are right in daily life and they are used intensively by individuals. They are used so intensively that most of the time, it is not even noticed that they are used. Metaphors have an important place in daily life and most of the thoughts are metaphorical (Lakoff \& Johnson, 2003). In addition, metaphors are a way of expressing social realities through linguistic tools (Döş, 2011). However, the concept of metaphor is explained as an effort to simplify issues that are difficult to understand (Renz, 2009), the mindset that helps us understand our environment (Morgan, 1998), and the art of explanation with the unknown (Arslan \& Bayrakçı, 2006). The Turkish Language Association (TLA) has defined the metaphor as a "figure of speech". Looking at the origin of the word, it derives from the Greek work metapherein, the combination of meta (between) and pherein (carry); namely, it means transferring (Konaklı \& Göğüş, 2013). When considered in this context, the word metaphor means transferring one content to another one (Nikitina \& Furuoka, 2008). When looking at the related explanations, it can be said that metaphors in general help transfer the meaning between concepts. In the light of these information and explanations, metaphor can be defined as a new way of thinking in which a powerful transfer of meaning is realized by comparing one of the two objects, events or concepts to the other in one aspect.

Education is a comprehensive concept (Botha, 2009) and includes work and actions that require effective management of educational activities at school (Akbaba-Altun \& Apaydın, 2013). At this very point, it can be said that teachers' perceptions of the concept of education in carrying out these educational activities are closely related to how they will affect their behaviors in the schools they work. In a study, it was found that the methods used by teachers 
depending on their experiences in the education process were structured according to their personal perceptions (Kasoutas \& Malamitsa, 2009). When considered in this context, it can be said that pedagogical formation certificate program students' metaphorical perceptions can directly affect their behavior in the schools where they will be employed in their professional lives. At the same time, the opinions of the students of the pedagogical formation certificate program on how the best, namely ideal, education should be are thought to be important in terms of their motivation towards the teaching profession. When the related literature was reviewed, metaphor studies related to the concept of education (Akbaba-Altun \& Apaydın, 2013; Örücü, 2014, Peculea, 2017; Şahin \& Sabancı, 2018; Turan, Yıldırım, \& Tıkman, 2016) were found to be limited, and no study on the ideal education concept was found. This study is thought to contribute to filling the gap in the literature. Metaphor, which is a tool here (Vadeboncoeur \& Torres, 2003), is used to reveal pedagogical formation certificate program students' understanding of education and ideal education concept.

The aim of this study is to reveal the perceptions of the concepts of education and ideal education by the students in the pedagogical formation certificate program through metaphors. For this purpose, answers to the following questions were sought:

1. What are the metaphors that the students in the pedagogical formation certificate program create regarding the concept of education?

2. Under which conceptual categories can the metaphors that the students in the pedagogical formation certificate program create regarding the concept of education be collected in terms of their common features?

3. How is the distribution of the conceptual categories related to the metaphors created by the students in the pedagogical formation certificate program about the concept of education according to their positive and negative features?

4. What are the metaphors that the students in the pedagogical formation certificate program create about ideal education?

5. Under which conceptual categories can the metaphors that the students in the pedagogical formation certificate program create regarding the concept of education be collected in terms of their common features?

\section{METHODS}

\section{Research Model}

In this study, which aimed to reveal pedagogical formation certificate program students' perceptions of the concepts of "education" and "ideal education" through metaphors, phenomenology pattern, one of the qualitative research patterns, was used. The aim of the phenomenological research is to reveal the thoughts of individuals about a phenomenon in detail based on their experiences, feelings and thoughts (Polatcan \& Kılınç, 2018). In this study, the thoughts of the students in the pedagogical formation certificate program about education, which is a social phenomenon (Çelikkaya, 1990), are discussed in detail.

\section{Study Group}

The study group of the research consisted of 98 students attending pedagogical formation certificate program in Nizip Faculty of Education at Gaziantep University in the 2018-2019 academic year. The study group was determined according to the criterion sampling method which is one of the purposive sampling methods. Criterion sampling is the sampling type in which the observation units consist of individuals, objects or situations with certain qualities and sampling units (objects, events, etc.) that meet the criteria set for the sampling (Büyüköztürk, Çakmak, Akgün, Karadeniz, \& Demirel, 2013). In this study, the criterion of "being a student in the pedagogical formation certificate program" was used for 98 participants. Some demographic characteristics of the participants in the study group of the study are given in Table 1. 
Table 1. Demographic characteristics of the participants

\begin{tabular}{|c|c|c|c|}
\hline Variables & Categories & $\mathbf{N}$ & $\%$ \\
\hline \multirow{2}{*}{ Gender } & Male & 36 & 36.74 \\
\hline & Female & 62 & 63.26 \\
\hline \multirow{4}{*}{ Age } & $18-22$ & 71 & 72.44 \\
\hline & $23-26$ & 11 & 11.23 \\
\hline & $27-30$ & 6 & 6.13 \\
\hline & 31 and above & 10 & 10.2 \\
\hline \multirow{7}{*}{$\begin{array}{c}\text { Undergraduate education } \\
\text { department }\end{array}$} & Sports Management & 36 & 36.74 \\
\hline & Mathematics & 21 & 21.43 \\
\hline & Turkish Language and Literature & 15 & 15.31 \\
\hline & Business Administration & 11 & 11.22 \\
\hline & Biology & 7 & 7.14 \\
\hline & Economics & 6 & 6.12 \\
\hline & English Language and Literature & 2 & 2.04 \\
\hline \multirow{2}{*}{$\begin{array}{l}\text { Continuing / not continuing } \\
\text { undergraduate education }\end{array}$} & Ongoing & 80 & 81.63 \\
\hline & Graduate & 18 & 18.37 \\
\hline Total & & 98 & 100 \\
\hline
\end{tabular}

According to Table 1, $36(36.74 \%)$ of the participants who were consulted within the scope of the study were male and $62(63.26 \%)$ were female. It is seen that $71(72.44 \%)$ of the participants are between the ages of 18 and 22, and $10(10.2 \%)$ are over the age of 31 . Participants seem to be studying in or have graduated from Sports Management (36 people), Mathematics (21 people), Turkish Language and Literature (15 people), Business Administration (11 people), Biology (7 people), Economics (6 people) and English Language and Literature (2 people). While $80(81.63 \%)$ of the participants continue their undergraduate education, $18(18.37 \%)$ graduated by completing their undergraduate education.

\section{Data Collection}

In this study, the data were collected through a structured interview form prepared by the researchers. In this form, firstly, the purpose of the research was clearly revealed. For the purpose of the research, brief information about metaphors was given and at the same time, an example of metaphor was added to the form for a better understanding of metaphors. For the purpose of the study, the participants were asked to answer the questions "What would be the first word or word group that come to your mind if you were to compare education to any object? Why?" and "What would be the first word or word group that come to your mind if you were to compare ideal education to any object? Why?" asked to answer the questions. Ylldirm and Şimşek (2016) stated that each individual can attribute different meanings to metaphors and therefore, the question of "how come" or "why" should be asked in order to understand for what purpose the metaphor created for a concept or phenomenon is used. In order to ensure integrity of answers in the form, below the first question "To me, education is like..... Because ....." statement and below the second question is "In my opinion, ideal education is like ... Because .......... ." are included. The researchers asked the participants to answer the questions in the form according to the patterns given below. At the same time, a section created to determine the demographic characteristics of the participants is also included in this form.

\section{Data Analysis}

In order to analyze the raw data obtained in the research, the filled forms were transferred to the electronic media. Demographic characteristics of the participants were determined according to the data transferred to the electronic media. On the other hand, the research data were subjected to content analysis and lists of the metaphors obtained about 
"education" and "ideal education" were created. Content analysis is a type of analysis that consists of examining and numerically expressing the content of any text or document (Ekiz, 2015). The metaphors specified in this process and the metaphors which seem to be incompatible with the cause of the metaphors in 6 forms were eliminated during the analysis phase. At the end of this listing process, the frequency (f) and the percentages (\%) of the metaphors were revealed. Then, the category development phase was initiated in order to examine the metaphors presented by the participants in terms of their common features. While determining the categories, metaphor studies which are very limited regarding the concept of education (Akbaba-Altun \& Apaydın, 2013; Peculea, 2017; Şahin \& Sabancl, 2018) were examined. Metaphors developed by the participants were examined, various categories were created by grouping similar concepts by considering the subject of metaphors and explanations about metaphors. At this stage, descriptive statements about high-frequency metaphors in each category are also included. Participants whose opinions were consulted were coded as K1, K2, K3... while direct quotations are included. At the same time, frequencies and percentages related to the categories were also revealed.

\section{Validity and Reliability}

In a qualitative research, reporting the collected data in detail and explaining how the researcher achieved the results are among the important criteria of the validity (Yildırım \& Şimşek, 2016). In this regard for the validity, it is important to explain how the data analysis process is carried out in the current research and to include detailed lists of the metaphors of the data obtained in the research. At the same time, it is also important for validity to include descriptive statements regarding high frequency metaphors in each category. Another feature that can be considered important in terms of ensuring validity in this research is the criterion sampling method, which is one of the purposive sampling methods.

The basic principle in terms of reliability in qualitative research is that any personal or professional impact that is likely to affect the process of collecting, analyzing and interpreting data that may affect the minds of those who use the findings positively or negatively should be indicated in the report (Patton, 2014). In order to ensure the reliability of the research, expert opinion was sought to confirm if the metaphors in the conceptual categories achieved in the research represent these categories. For this purpose, two faculty members working in Nizip Faculty of Education at Gaziantep University were asked about their opinions regarding to what extent the metaphors under these categories represent the category. Some corrections were made again in line with the opinions of the experts. On the other hand, it is important for the reliability to identify the students in the pedagogical formation certificate program, who are the source of data in the research, and to present their demographic features.

\section{RESULTS}

In this section, the metaphors that the students in the pedagogical formation certificate program created about the concepts of "education" and "ideal education" the conceptual categories related to these metaphors and the features of these categories are included. There are also excerpts from the participants' opinions.

\section{The metaphors that the students in the pedagogic formation certificate program created about the concept of "education"}

In accordance with the first sub-purpose of the research, as a result of the analysis of the data obtained, the metaphors the students created for the concept of "education", the frequencies and percentages of the metaphors are given in Table 2. 
Table 2. The metaphors that the students in the pedagogic formation certificate program created about the concept of "education"

\begin{tabular}{|c|c|c|c|c|c|c|c|c|}
\hline Education metaphor & f & $\%$ & Education metaphor & f & $\%$ & Education metaphor & $\mathbf{f}$ & $\%$ \\
\hline Ascent & 1 & 1,02 & Food & 1 & 1,02 & Play dough & 1 & 1,02 \\
\hline Bell & 1 & 1,02 & Football & 1 & 1,02 & Pomegranate & 1 & 1,02 \\
\hline Blackboard & 1 & 1,02 & Forest & 1 & 1,02 & Prescription glasses & 1 & 1,02 \\
\hline Blinder & 1 & 1,02 & Fruit & 1 & 1,02 & Printer & 2 & 2,04 \\
\hline Book & 8 & 8,16 & Global warming & 1 & 1,02 & Refrigerator & 1 & 1,02 \\
\hline Breath & 1 & 1,02 & Grindstone & 1 & 1,02 & Rotten fruit & 1 & 1,02 \\
\hline Cage & 2 & 2,04 & Harvest & 1 & 1,02 & Rule & 1 & 1,02 \\
\hline Cake mold & 1 & 1,02 & Hole in the balloon & 1 & 1,02 & Sapling & 2 & 2,04 \\
\hline Car & 1 & 1,02 & Horse racing & 3 & 3,06 & Sea & 1 & 1,02 \\
\hline Carpenter & 1 & 1,02 & Journey & 1 & 1,02 & Season & 1 & 1,02 \\
\hline Carom & 1 & 1,02 & Knife & 1 & 1,02 & Sieve & 1 & 1,02 \\
\hline Clock & 1 & 1,02 & Ladder & 2 & 2,04 & Sky & 2 & 2,04 \\
\hline Closed box & 2 & 2,04 & Lamp & 1 & 1,02 & Smartphone & 1 & 1,02 \\
\hline Computer & 1 & 1,02 & Learning to walk & 1 & 1,02 & Sun & 1 & 1,02 \\
\hline Construction & 1 & 1,02 & Life & 4 & 4,08 & Television & 1 & 1,02 \\
\hline Dark room & 1 & 1,02 & Locomotive & 1 & 1,02 & The Yin Yang & 1 & 1,02 \\
\hline Deadlock & 1 & 1,02 & Mitochondrion & 1 & 1,02 & Thorny rose & 1 & 1,02 \\
\hline Encyclopedia & 1 & 1,02 & Money & 1 & 1,02 & Transparent sphere & 1 & 1,02 \\
\hline Endless road & 1 & 1,02 & Obstacle road & 1 & 1,02 & Tree & 9 & 9,18 \\
\hline Family & 1 & 1,02 & Oxygen & 2 & 2,04 & Unsolvable riddle & 1 & 1,02 \\
\hline Fertile soil & 1 & 1,02 & Parent & 1 & 1,02 & Vault & 1 & 1,02 \\
\hline Fiction & 1 & 1,02 & Pen & 1 & 1,02 & Water & 2 & 2,04 \\
\hline Field & 1 & 1,02 & Pencil sharpener & 2 & 2,04 & Wheel of Fortune & 1 & 1,02 \\
\hline TOTAL & & & & & & & 98 & 100 \\
\hline
\end{tabular}

According to Table 2, a total of 98 metaphors were created by 98 students in the pedagogical formation certificate program. When the identical ones are grouped, it is seen that 69 different metaphors are created. The highest frequency of these metaphors seem to be tree (f $=9)$, book $(f=8)$, life $(f=4)$, horse racing $(f=3)$, sapling $(f=2)$, sky $(f=2)$, cage $(f=2)$, pencil sharpener $(\mathrm{f}=2)$, closed box $(\mathrm{f}=2)$, ladder $(\mathrm{f}=2)$, oxygen $(\mathrm{f}=2)$, water $(\mathrm{f}=2)$ and printer $(\mathrm{f}=$ 2), respectively.

\section{Conceptual categories related to the metaphors created by the students in the pedagogical formation certificate program about the concept of "education"}

In accordance with the second sub-purpose of the research, the conceptual categories related to the metaphors that the students in the pedagogical formation certificate program created about the concept of "education", and the frequencies and percentages related to these categories are given in Table 3.

Table 3. Conceptual categories related to the metaphors created by the students in the pedagogical formation certificate program about the concept of "education"

\begin{tabular}{lcrl}
\hline \multicolumn{1}{c}{ Categories (n = 11) } & f & \% & \multicolumn{1}{c}{ Metaphors } \\
\hline Individual and social development tool & 27 & & $\begin{array}{l}\text { Tree (6), car, knife, refrigerator, parent, } \\
\text { sapling (2), sharpener (2), cake mold, rule, } \\
\text { book (2), lamp, carpenter, prescription glasses, } \\
\text { forest, strainer, field, fertile soil, printer, } \\
\text { learning to walk }\end{array}$ \\
\hline Challenging, preventive and limiting & 15 & $15.32 \begin{array}{l}\text { Blinder, horse race (3), thorny rose, obstacle } \\
\text { road, closed box, blackboard, cage (2), book, } \\
\text { global warming, clock, endless road, ascent }\end{array}$ \\
\hline Lifelong learning & 12 & 12.24 & $\begin{array}{l}\text { Tree, sea, sky, life (2), book (3), ladder, pen, } \\
\text { journey, printer }\end{array}$ \\
\hline
\end{tabular}


Table 3. (cont'd)

\begin{tabular}{|c|c|c|c|}
\hline Categories $(n=11)$ & f & $\%$ & Metaphors \\
\hline Systematic structure and process & 10 & 10.20 & $\begin{array}{l}\text { Tree, grindstone, harvest, construction, } \\
\text { fiction, locomotive, ladder, fruit, } \\
\text { mitochondrion, food }\end{array}$ \\
\hline Purposeless and useless & 8 & 8.16 & $\begin{array}{l}\text { Hole in the balloon, rotten fruit, football, } \\
\text { transparent sphere, life, dark room, vault, } \\
\text { television }\end{array}$ \\
\hline Source of Information & 6 & 6.12 & $\begin{array}{l}\text { Encyclopedia, computer, Wheel of Fortune, } \\
\text { sky, book, pomegranate }\end{array}$ \\
\hline Basic need & 6 & 6.12 & Life, book, oxygen (2), breath, water \\
\hline Complex structure and process & 5 & 5.10 & $\begin{array}{l}\begin{array}{l}\text { Unsolvable riddle, closed box, carom, } \\
\text { deadlock, money }\end{array} \\
\end{array}$ \\
\hline Personal differences & 5 & 5.10 & $\begin{array}{l}\text { Smartphone, play dough, water, the Yin Yang, } \\
\text { bell }\end{array}$ \\
\hline Enlightening and guiding & 2 & 2.04 & Family, Sun \\
\hline Compatible with change and development & 2 & 2.04 & Tree, season \\
\hline TOTAL & 98 & 100 & \\
\hline
\end{tabular}

When Table 3 is examined, it is seen that 11 conceptual categories related to the metaphors that the students in the pedagogical formation certificate program created about the concept of education have been generated. The conceptual categories with the highest frequencies are, respectively, individual and social development tool ( $f=27$ ), challenging, preventive and limiting $(f=15)$, lifelong learning $(f=12)$, systematic structure and process $(f=$ 10). Those with the least frequency of these conceptual categories are observed to be, respectively, complex structure and process $(f=5)$ compatible with change and development ( $f$ $=2)$, illuminating and guiding $(f=2)$, personal differences $(f=5)$.

The descriptive statements obtained from the participants regarding the metaphors in the first 3 categories with high frequencies are given below.

Individual and social development tool: 27 (27.56\%) of the total metaphors created by the students in the pedagogical formation certificate program are in this category. These metaphors created are, respectively, tree, car, knife, refrigerator, parent, sapling, pencil sharpener, cake mold, rule, book, lamp, carpenter, prescribed glasses, forest, sieve, field, fertile soil, printer and learning to walk (19 of them). Below are quotations from the participants regarding some of the metaphors in this category:

To me, education is like a pencil sharpener. Because an obtuse pencil has no potential. You must sharpen the pencil before you give it to the true hand. So is man. It is a pencil, but the tip is obtuse. It needs a pencil sharpener, that is education, to produce, cultivate and lead. K5 (Male, 18-22 years old, Sports Management)

To me, education is like a tree. Because the information we receive during the training process informs us prospectively and meets our need. Just like when we eat the fruits we get from the tree, it meets our food needs...K25 (Male, 18-22 years old, Sports Management)

To me, education is like a baby learning to walk. Because after the baby is born, they gradually acquire psychomotor abilities. Education is similar to this. The first step to be human. K31 (Male, 18-22 years old, Sports Management)

To me, education is like a book. Because we learn and get something at every moment of education. Just like we make out different meanings each time we read a book. K82 (Female, 23-26 years old, Economics)

Challenging, preventive and limiting: 15 (15.32\%) of the total metaphors created by the students in the pedagogical formation certificate program are in this category. These metaphors created are, respectively, blinder, horse race, thorny rose, obstacle road, closed box, blackboard, cage, book, global warming, clock, endless road and ascent (12 of them). Below are the statements of some participants regarding the metaphors in this category: 
To me, education is like a horse race. Because we have to constantly compete with someone. As what is requested is completed, more is requested. You're running, you're running, but your hand is still empty. K84 (Female, age 31 and older, Business Administration)

To me, education is like a cage. Because education in our country is done in a way that is given between four walls and which I don't think is very useful. K64 (Female, aged 18-22, Mathematics)

To me, education is like an endless path. Because we are in constant progress, but we do not know what will be the end, and we face obstacles all the time. K30 (Male, 18-22 years old, Sports Management)

To me, education is like an obstacle road. Because the current system is up and down and with obstacles. It is difficult to study and is not a good education. K19 (Female, 18-22 years old, Sports Management)

Lifelong learning: 12 (12.24\%) of the total metaphors created by the students in the pedagogical formation certificate program are in this category. These metaphors created are, respectively, tree, sea, sky, life, book, ladder, pen, journey and printer ( 9 of them). Below are some quotations from the participants regarding the metaphors in this category:

To me, education is like a book. Because when you turn every page of the book, you learn something, this is education at work. As days go by, you learn something as a new page turns, and this learning never ends. K53(Woman, 18-22 years old, English Language and Literature)

To me, education is like a journey. Because something is learned at every step of the way. Education is like a lifelong journey for man. K21 (Male, 18-22 years old, Sports Management)

To me, education is like the sky. Because education is not just a period in a certain process. The reason I compare it to the sky is that it has a very wide angle and is in the continuation of our life. K74 (Female, 18-22 years old, Mathematics)

\section{The distribution of the conceptual categories about the concept of education according to their positive and negative features}

In accordance with the third sub-purpose of the research, the distribution of the conceptual categories related to the metaphors created by the students in the pedagogical formation certificate program about the concept of "education" according to their positive and negative features is given in the table below.

Table 4. The distribution of the conceptual categories about the concept of education according to their positive and negative features

\begin{tabular}{|c|c|c|c|}
\hline & Categories & $\mathbf{f}$ & $\%$ \\
\hline \multirow{8}{*}{$\begin{array}{l}\text { Positive categories }(\mathrm{f}=70 ; \\
\qquad 71.42 \%)\end{array}$} & Individual and social development tool & 27 & 27.56 \\
\hline & Lifelong learning & 12 & 12.24 \\
\hline & Systematic structure and process & 10 & 10.20 \\
\hline & Source of Information & 6 & 6.12 \\
\hline & Basic need & 6 & 6.12 \\
\hline & Personal differences & 5 & 5.10 \\
\hline & Enlightening and guiding & 2 & 2.04 \\
\hline & Compatible with change and development & 2 & 2.04 \\
\hline \multirow{3}{*}{$\begin{array}{c}\text { Negative categories }(\mathrm{f}= \\
28 ; 28.58 \%)\end{array}$} & Challenging, preventive and limiting & 15 & 15.32 \\
\hline & Purposeless and useless & 8 & 8.16 \\
\hline & Complex structure and process & 5 & 5.10 \\
\hline
\end{tabular}

Considering Table 4, 8 of the conceptual categories created for the concept of education (individual and social development tool, lifelong learning, systematic structure and process, source of information, basic need, personal differences, enlightening and guiding, adapting to change and development) are the categories of metaphors with positive meaning. These positive categories make up $71.42 \%$ ( $f=70$ ) of all categories created. On the other hand, it is seen that 3 of the categories created for the concept of education (compelling, preventive and 
restrictive, aimless and useless, complex structure and process) are categories consisting of metaphors with negative meaning. It is observed that the negative categories make up $28.58 \%$ ( $\mathrm{f}=28$ ) of all categories created.

\section{The metaphors that the students in the pedagogic formation certificate program created about the concept of "education"}

According to the fourth sub-purpose of the research, as a result of the analysis of the data obtained, the metaphors that the students of the pedagogical formation certificate program created about the concept of "ideal education", the frequencies and percentages of the metaphors are given in Table 5.

Table 5. The metaphors that the students in the pedagogic formation certificate program created about the concept of "ideal education"

\begin{tabular}{|c|c|c|c|c|c|c|c|c|}
\hline $\begin{array}{c}\text { Ideal education } \\
\text { metaphor }\end{array}$ & f & $\%$ & $\begin{array}{c}\text { Ideal education } \\
\text { metaphor }\end{array}$ & f & $\%$ & $\begin{array}{c}\text { Ideal education } \\
\text { metaphor }\end{array}$ & $\mathbf{f}$ & $\%$ \\
\hline Aquarium & 1 & 1,02 & Healthy person & 1 & 1,02 & Rain & 1 & 1,02 \\
\hline Bag & 1 & 1,02 & House & 2 & 2,04 & Rainbow & 1 & 1,02 \\
\hline Ball & 1 & 1,02 & Infinity symbol & 1 & 1,02 & Ripe fruit & 1 & 1,02 \\
\hline Book & 3 & 3,06 & Internet & 1 & 1,02 & River & 1 & 1,02 \\
\hline Bucket & 1 & 1,02 & Irrational numbers & 1 & 1,02 & Sandbag & 1 & 1,02 \\
\hline Building & 1 & 1,02 & Journey & 1 & 1,02 & Sapling & 3 & 3,06 \\
\hline Car & 1 & 1,02 & Judge & 1 & 1,02 & Skeleton & 2 & 2,04 \\
\hline Carboy & 1 & 1,02 & Kite & 1 & 1,02 & Sky & 2 & 2,04 \\
\hline Castle & 1 & 1,02 & Library & 1 & 1,02 & Smartphone & 1 & 1,02 \\
\hline Children's park & 1 & 1,02 & Life & 4 & 4,08 & Software & 1 & 1,02 \\
\hline Clean pool & 1 & 1,02 & Light & 2 & 2,04 & Sports & 1 & 1,02 \\
\hline Computer & 2 & 2,04 & Machine & 2 & 2,04 & Steering wheel & 1 & 1,02 \\
\hline Discovery & 1 & 1,02 & Menu & 1 & 1,02 & Step & 1 & 1,02 \\
\hline Dream & 1 & 1,02 & Modified car & 1 & 1,02 & Strategy game & 1 & 1,02 \\
\hline Empty bucket & 1 & 1,02 & Nature & 1 & 1,02 & Sun & 2 & 2,04 \\
\hline Field & 1 & 1,02 & Open window & 1 & 1,02 & Swiss army knife & 1 & 1,04 \\
\hline Flower & 1 & 1,02 & Orchard & 1 & 1,02 & The right medicine & 1 & 1,02 \\
\hline Flower garden & 1 & 1,02 & Oxygen & 1 & 1,02 & Time & 1 & 1,02 \\
\hline Folder & 1 & 1,02 & Path & 1 & 1,02 & Train going on the rail & 1 & 1,02 \\
\hline Food processor & 1 & 1,02 & Pencil & 2 & 2,04 & Train rail & 1 & 1,02 \\
\hline Forest & 2 & 2,04 & Pencil sharpener & 1 & 1,02 & Warm family & 1 & 1,02 \\
\hline Fruit tree & 2 & 2,04 & Pencil with eraser & 1 & 1,02 & Water & 2 & 2,04 \\
\hline Game & 2 & 2,04 & Playground & 3 & 3,06 & Waterfall & 1 & 1,02 \\
\hline Garden & 2 & 2,04 & Pyramid & 1 & 1,02 & Wood & 1 & 1,02 \\
\hline Grindstone & 2 & 2,04 & Puzzle & 2 & 2,04 & & & \\
\hline TOTAL & & & & & & & 98 & 100 \\
\hline
\end{tabular}

According to Table 5, a total of 98 metaphors were created by 98 students in the pedagogical formation certificate program about ideal education. When the identical ones are grouped, it is seen that 74 different metaphors occur. The metaphors with the highest frequencies are, respectively, life $(f=4)$, sapling $(f=3)$, book $(f=3)$, playground $(f=3)$, garden $(f=2)$, computer $(f=2)$, grindstone $(f=2)$, house $(f=2)$, sky $(f=2)$, the Sun $(f=2)$, light $(f=2)$, skeleton $(f=2)$, pen $(f=2)$, machine $(f=2)$, fruit tree $(f=2)$, game $(f=2)$, water $(f=2)$ and puzzle $(\mathrm{f}=2)$.

Conceptual categories related to the metaphors created by the students in the pedagogical formation certificate program about the concept of "ideal education"

In line with the fifth sub-purpose of the study, the conceptual categories regarding the metaphors that the students in the pedagogical formation certificate program created about "ideal education", the frequencies and percentages related to these categories are given in Table 6. 
Table 6. Conceptual categories related to the metaphors created by the students in the pedagogical formation certificate program about the concept of "ideal education"

\begin{tabular}{|c|c|c|c|}
\hline Categories $(n=11)$ & $\mathbf{f}$ & $\%$ & Metaphors \\
\hline Systematic structure and process & 20 & 20.41 & $\begin{array}{l}\text { Aquarium, car, building, empty bucket, } \\
\text { carboy, grindstone (2), skeleton, book, } \\
\text { machine (2), fruit tree (2), pyramid, train } \\
\text { going on the rail, healthy person, warm } \\
\text { family, puzzle (2), road }\end{array}$ \\
\hline Personal differences & 18 & 18.37 & $\begin{array}{l}\text { Smartphone, garden (2), flower garden, } \\
\text { steering wheel, the right medicine, home, } \\
\text { judge, imagination, internet, pen, discovery, } \\
\text { bucket, menu, orchard, wood, forest, water }\end{array}$ \\
\hline Individual and social development tool & 14 & 14.29 & $\begin{array}{l}\text { Step, flower, sapling (3), skeleton, castle, } \\
\text { pencil, sharpener, ripe fruit, field, clean pool, } \\
\text { train rail, rain }\end{array}$ \\
\hline Lifelong learning & 12 & 12.24 & $\begin{array}{l}\text { River, rainbow, sky, life (2), irrational } \\
\text { numbers, book, sandbag, oxygen, infinity } \\
\text { symbol, journey, time }\end{array}$ \\
\hline Doing-living & 12 & 12.24 & $\begin{array}{l}\text { Children's park, nature, home, life (2), game } \\
\text { (2), playground (3), sports, kite }\end{array}$ \\
\hline Enlightening and guiding & 5 & 5.10 & Sun (2), light (2), pencil with eraser \\
\hline Source of Information & 5 & 5.10 & Computer, book, library, forest, waterfall \\
\hline Compatible with change and development & 4 & 4.08 & Open window, computer, ball, software \\
\hline Life-facilitating tool & 3 & 3.06 & Swiss army knife, food processor, bag \\
\hline Specialization & 3 & 3.06 & Folder, modified car, strategy game \\
\hline Basic need & 2 & 2.04 & Sky, water \\
\hline TOTAL & 98 & 100 & \\
\hline
\end{tabular}

When Table 6 is examined, it is observed that 11 conceptual categories related to the metaphors that the students in the pedagogical formation certificate program created about the concept of ideal education have been generated. The conceptual categories with the highest frequencies are, respectively, systematic structure and process $(\mathrm{f}=20)$, personal differences $(\mathrm{f}=$ $18)$, individual and social development tool $(\mathrm{f}=14)$, lifelong learning $(\mathrm{f}=12)$ and doing-living ( $\mathrm{f}$ $=12)$. Those with the lowest frequencies are, respectively, basic need $(\mathrm{f}=2)$, specialization $(\mathrm{f}=$ 3 ) and life-facilitation tool ( $\mathrm{f}=3$ ).

The quotations from the participants regarding the metaphors in the first 3 categories with the highest frequency among these categories are given below.

Systematic structure and process: 20 (20.41\%) of the total metaphors created by the students in the pedagogical formation certificate program are in this category. These metaphors created are, respectively, aquarium, car, building, empty bucket, carboy, grindstone, skeleton, book, machine, fruit tree, pyramid, train going on the rail, healthy person, warm family, puzzle and path (16 of them). Below are some quotations from participants' opinions regarding some of the metaphors in this category.

To me, ideal education is like a grindstone. Because if you don't throw anything new, it will grind itself. All parts follow one another. It works if all parts work; otherwise, they will be interrupted. $\mathrm{K} 9$ (Female, 18-22 years old, Sports Management)

To me, ideal education is like a machine. Because everything must work within the framework of a certain discipline and rules. K44 (Woman, 18-22 years old, Turkish Language and Literature)

To me, ideal education is like a puzzle. Because ideal education is complementary. If something is missing for the sake of education somewhere in life, the puzzle will not be completed and the education of the individual will be left unfinished. K69 (Female, 31 years of age and above, Business Administration) 
To me, ideal education is like a skeleton. Because if any part is missing or damaged in the skeletal system, a physical and emotional malfunction occurs in the body. If a problem occurs in the education system as well, the entire education system will deteriorate. K94 (Male, 18-22 years old, Mathematics)

Personal differences: 18 (18.37\%) of the total metaphors created by the students of the pedagogical formation certificate program are in this category. These metaphors created are, respectively, smartphone, garden, flower garden, steering wheel, the right medicine, judge, imagination, internet, pen, discovery, bucket, menu, orchard, wood, forest, game island and water (17 of them). Below are some quotations from participants' opinions regarding some of the metaphors in this category.

To me, education is like a steering wheel. Because education should not lead me, but I should lead education. Education shouldn't make me a robot or restrict me. K7 (Male, 18-22 years old, Sports Management)

To me, it is like an ideal education menu. Because people want to be educated in a way that suits their taste, that they want, and that they can get efficiency. K12 (Female, 18-22 years old, Sports Management)

To me, ideal education is like a game island. Because every person's interest is different and they have to educate themselves accordingly. Trying to educate every person in the same way will only harm them. $\mathrm{K} 40$ (Female, 18-22 years old, English Language and Literature)

To me, ideal education is like the Internet. Because, as in the social environment, one should improve oneself in the way they want. While one can research and develop own ideas on the internet, it should be the same at school, as well. K89 (Male, 18-22 years old, Mathematics)

Individual and social development tool: 14 (14.29\%) of the total metaphors created by the students in the pedagogical formation certificate program are in this category. These metaphors created are respectively; step, flower, sapling, skeleton, castle, pencil, pencil sharpener, ripe fruit, field, clean pond, train rail and rain (12 of them). Below are quotations from the participants regarding some of the metaphors in this category:

To me, ideal education is like a field. Because ideal education is like the efficiency of the education that the teacher gives to the student. Just as you cultivate the field, spray and water it, and you will get your crop, education should be so. With efficient and qualified education, we raise generations and raise individuals who are beneficial to humanity. K5 (Male, 18-22 years old, Sports Management)

To me, ideal education is like a castle. Because ideal education is like obtaining solid works by combining parts that are meaningless one by one. Ideal education improves everyone's defense mechanism. It makes the individual self-confident and conscious. K37 (Woman, 18-22 years old, Turkish Language and Literature)

To me, ideal education is like a skeleton. Because it is the skeletal system that keeps the body alive. The stronger your skeletal system, the stronger you will be. The stronger your education, the better equipped you will be. K88 (Female, 27-30 years old, Business Administration)

\section{DISCUSSION and CONCLUSIONS}

In this study, it was basically aimed to reveal pedagogical formation certificate program students' perceptions of the concepts of education and ideal education through metaphors. The data obtained in line with this basic purpose were analyzed by considering the sub-objectives of the research and the findings of the research were generated. Based on the findings obtained in the study, the results of the research were revealed. At the same time, the results are compared with the findings obtained in similar studies, and the related literature, and various comments and suggestions are made.

When the results put forward by the students in the pedagogical formation certificate program regarding the concept of education are examined, it is observed that 69 different valid metaphors were created by 98 students in the study group. Among these metaphors, tree, book, life and horse race metaphors were used the most, respectively. When the relevant literature is 
reviewed, it is understood that the tree metaphor was used with different meanings in various studies. The study by Peculea (2017) shows that the most commonly used metaphor for the concept of education by participants is the tree metaphor, and this metaphor is in the category of "development". In the study conducted by Akbaba-Altun and Apaydın (2013), it is seen that tree, fruit-bearing tree and sapling metaphors are used for the concept of education by female and male students and education is characterized as a process that provides continuous development by using these metaphors. On the other hand, the research carried out by Saban (2008) reported that the tree metaphor was used for the concept of school, and that the school nurtured the students as socially beneficial individuals and supported the individual development of the students. Education constitutes an indispensable process both individually and socially for the individual to learn social behavior in the process of joining a new society and for the society to raise individuals who can meet the social expectations (Kumral, 2017). The majority of the participants who used the tree metaphor in the present research emphasized the aspect of education as an instrument of individual and social development. In this respect, it is seen that the mentioned studies and related literature support the findings and results obtained in the present study. One of the metaphors most used by the students of the pedagogical formation certificate program for the concept of education in the research appears to be the book metaphor. The book metaphor is frequently used in different studies using metaphors. For example, in the study conducted by Şahin and Sabancı (2018), the participants used the book metaphor regarding the concept of education and considered the education as an academic development tool. In the study conducted by Özdemir and Akkaya (2013), the participants used the book metaphor for the concept of school and attribute the meaning of the place of knowledge and enlightenment to the school with this metaphor. It is seen that the students of the pedagogical formation certificate program, whose opinions are consulted within the scope of the current study, use the metaphor of the book to attach the meanings of individual and social development, lifelong learning and basic needs to education. In the study conducted by Güven, Yıldırım and Çelen (2014), it is seen that one of the most used metaphors for the concept of lifelong learning is the book. It can be said that the findings obtained in the current research and the research findings made by Güven, Yıldırım, and Çelen (2014) overlap, the research findings made by Şahin and Sabancı (2018) partially overlap, and differ from those found by Özdemir and Akkaya (2013).

Within the scope of the current research, one of the interesting metaphors about the concept of education can be said to be the horse race. Participants stated that with this metaphor, personal characteristics and abilities were not given importance in education and they were competing with each other, assuming that all students had the same characteristics. In the study conducted by Örücü (2014) on prospective teachers, the participants emphasized the competitive and exam-oriented structure of the Turkish Education System using the horse racing metaphor for the Turkish Education System. On the other hand, in the research conducted by Nalçacı and Bektaş (2012), it was stated that the school was seen as a race environment through various metaphors used by teacher candidates. With the horse racing metaphor obtained within the scope of the current research, especially the negative features of education were emphasized and it was observed that similar findings were found in the studies conducted using metaphors related to different concepts related to education.

The metaphors used by pedagogical formation certificate program students for the concept of education are grouped under 11 conceptual categories in terms of their common characteristics. It is seen that 8 of these categories have positive characteristics and 3 of them have negative characteristics. It is understood that the students of the pedagogical formation certificate program produce metaphors with more positive characteristics regarding the concept of education. The metaphors used for the concept of education were gathered in the category of individual and social development tools the most. Individual development and social development have a directly proportional relationship. Considering that the society is made up of individuals, the increase of the education level of the individuals means the increase of the education level of the societies. In different studies, findings supporting the findings of the current study were found. In the study conducted by Peculea (2017), it is seen that the 
metaphors created by the first-year undergraduate students are mostly gathered in the category of "development" which emphasizes personal and social development. In the study conducted by Şahin and Sabancl (2018), it is seen that one of the categories in which the metaphors used by the pedagogical formation students for the education concept are mostly collected is the "source of change and development". It can be said that the findings obtained in the current research overlap with the findings of the relevant studies in the literature. On the other hand, in the current research, the other category where the metaphors used by the students of the pedagogical formation certificate program were collected the second most appears to be lifelong learning. Although the concept of lifelong learning has entered our lives more with the concept of globalization, lifelong learning is not a new concept according to Brown (2018) and has been involved in education thinking since Plato. Lifelong learning is a learning approach that aims individuals to constantly acquire new knowledge, skills and competencies, update their existing knowledge, skills and competencies, and integrate what they have learned with the old ones (Şişman, 2018). Metaphors used in this category by the students in the pedagogical formation certificate program (tree, sea, sky, life, book, ladder, ballpoint pen, long journey, printer) emphasize that education does not cover a certain period in human life, but continues from birth to death. In the study conducted by Şahin and Sabancl (2018), there are findings that the students in the pedagogical formation certificate program use metaphors that education is a lifelong process. Lifelong learning has an important place in today's societies, where knowledge has become dynamic, that is, can change at any time. People have to follow the changes and transformations in order to be accepted professionally and socially and adapt themselves to these changes. This finding obtained within the scope of the current research is very valuable in terms of revealing the awareness of students of pedagogical formation certificate program about lifelong learning. The other categories under which the positive metaphors used by the students in the pedagogical formation certificate program pedagogical regarding education are collected appear to be systematic structure and process, source of information, basic need, personal differences, enlightening and guiding, and compatible with change and development

In addition to these positive categories, the categories consisting of metaphors with negative meaning were also found. The negative metaphors that the students of pedagogical formation certificate program use regarding education concept were collected in the categories compelling, prohibitive and restrictive, complex structure and process, purposeless and useless. Participants stated that education was a challenging and limiting process with obstacles with the various metaphors they used (horse race, blinders, thorny rose, obstacle road, closed box, cage, endless road, ascent, etc.). This category is a very important finding as it is the 2nd category with the highest frequency among the 11 conceptual categories in which metaphors for education are collected. According to Özden (2018), metaphors express a person's knowledge, interest, love, hate, etc. on a subject. Their emergence is closely related to the experiences of the people in the subject. Therefore, the metaphors that the students of the pedagogical formation certificate program put forward in this direction may be related to the various difficulties they faced in their educational processes. On the other hand, in the study carried out by Örücü (2014), the metaphors used by prospective teachers regarding the Turkish Education System appear to be gathered in negative themes such as chaos / uncertainty, mechanical / bureaucratic functioning, competition / exam-centeredness, inability to reach the goal, puzzle, inefficiency and obstacle before freedom. When comparing these themes with the categories created in the current research, it can be said that they are parallel in terms of content and meaning although there are differences in naming.

When the metaphors created by the students of pedagogical formation certificate program about "ideal education" are examined, it is seen that 74 valid metaphors were created by 98 students in the study group. Among these metaphors, life, sapling, book and playground metaphors were used most frequently, respectively. Participants expressed their expectations for education through the metaphors they used for ideal education. In this research, the participants emphasized the necessity of education to make individuals acquire knowledge, skills and attitudes to be used in daily life and that it should be a process that should continue throughout life with the life metaphor they used. In the study conducted by Özdemir and 
Akkaya (2013), the participants used the life metaphor for the ideal school, and by using this metaphor, they regarded the school as a place where development and maturation was achieved. It can be thought that different meanings were attached to the metaphor of life due to its use for different concepts (ideal education and ideal school) in these studies. It is very important that ideal education is consistent with real life. Aithal and Aithal (2015) stated in their study that an ideal education system should not only prepare individuals for the world of work, but also empower them to adapt to different situations in the world of work and transform people according to new and emerging needs. Therefore, it is important for participants to emphasize the necessity of the ideal education to make individuals acquire knowledge, skills and attitudes to be used in daily life by using life metaphor. On the other hand, Karaküçük (2012) stated that child-youth education is important in all of the ideal education models in various utopias, and that adult education should be followed as the result and continuation of formal education. Therefore, the fact that participants use the metaphor of life to emphasize that ideal education is a lifelong process is consistent with this view in the models of ideal education in various utopias. One of the most used and very remarkable metaphors about ideal education appears to be the playground. The participants emphasized that the educated person should be active, learning by doing-living and training should be fun by using the playground metaphor for ideal education. Active learning is a learning situation in which the learner is actively involved in the learning process, guides his own learning, uses higher thinking and decision-making skills and cooperates with other learners (Kalem \& Fer, 2003). It can be said that games also play an important role in the active learning process. Games, as well as being a tool for students to actively take care of and continue their activities individually, also provide environments that allow them to learn by doing-living (Akın \& Atıcl, 2015). In some studies, it is seen that metaphors related to the game are used. In the study conducted by Saban (2008), the participants used the game park metaphor for the concept of school and this metaphor was in the category of "school as a nice and beautiful place". In the study conducted by Özdemir and Akkaya (2013), the participants used the computer game metaphor for the ideal school and designed the ideal school as a place of happiness and excitement. In order for the education given in schools to be interesting and attractive for students, it is considered important for students to be active in this process and to make this process enjoyable and enjoyable for the students who are the subjects of education.

The metaphors used by pedagogical formation students for the concept of education are grouped under 11 conceptual categories in terms of their common characteristics. Among these categories, systematic structure and process category came to the fore in terms of having the highest frequency. Gedikoğlu (2005) indicated that a political party-free education policy has never been formed in Turkey, the system has never been established due to changing policies from one government to another, the continuity of education policies cannot be maintained, and changing governments have transformed the system into a jigsaw board. In the study conducted by Örücü (2014), it is seen that the metaphors of the participants regarding the Turkish Education System are mostly gathered under the theme of "chaos / uncertainty". It can be said that frequent changes in the education system cause uncertainties and hence the trust of people in education is shaken. In this regard, it seems common in the current research that the participants have the expectation of systematic structure and process regarding ideal education. Another important category in which metaphors about ideal education are collected seems to be personal differences. The participants stated that personal characteristics and differences should be taken into consideration for an ideal education through the metaphors they use. According to Aktepe (2005), each individual has different abilities, intelligence, interest, learning style, prior knowledge and motivations. The importance and value of education is plausible if importance is given to these individual differences, and if the individuals are offered educational activities in the areas of their talent, interest and intelligence. It can be said that in education systems where personal characteristics and differences are not taken into consideration, individuals cannot find the environment to develop their interests, abilities and tendencies. One of the remarkable categories of metaphors used by students of the pedagogical formation certificate program is compatible with change and development category. According 
to Çolakoğlu (2005), the most important feature that defines the age we live in is rapid change, and very different changes and innovations are experienced economically, culturally, politically, socially and technologically. Changes and innovations in various fields also affect education directly or indirectly in terms of purpose, structure and process. For this reason, it is very important for various elements (student, teacher, school manager, parents, physically school, education programs, etc.) that affect education and are affected by education, to adapt to the changes and innovations. For this reason, it is quite remarkable and important that students of the pedagogical formation certificate program present metaphors in this direction regarding ideal education.

Considering the findings and results obtained in the study, the following suggestions can be made:

$\checkmark$ Frequent changes and uncertainties that individuals encounter in their education life negatively affect their perceptions about education. For this reason, changes in education should be made in a planned way. For this, firstly, the infrastructure of the change should be prepared correctly and pilot studies regarding the change should be done. Another important issue in this regard is to take the opinions of the relevant stakeholders in the change and to be informed about the processes of realizing the change.

$\checkmark$ In order to prevent people from feeling in a constant race in their educational life, education life should be directed by taking into account the personal characteristics of each individual. For this reason, it is necessary to carry out studies related to getting to know and discover students regularly.

$\checkmark$ In order to increase the awareness of people about lifelong learning, learning outcomes related to this subject should be included in the programs of the courses at different levels of formal education. At the same time, building structures and facilities that will encourage lifelong learning in various life units (provinces, districts, towns, etc.) can be useful both individually and socially.

$\checkmark$ It is recommended to include various activities in the pedagogical formation certificate program in order to eliminate the negative perceptions of students of the pedagogical formation certificate program towards education and increase their motivation towards the teaching profession. In this regard, watching movies about education, reading books and organizing conferences can be effective.

\section{REFERENCES}

Aithal, P., \& Shubhrajyotsna Aithal, S. (2015). An innovative education model to realize ideal education system. International Journal of Scientific Research and Management (IJSRM), 3(3), 2464-2469.

Akın, F. A., \& Atıcı, B. (2015). Oyun tabanlı öğrenme ortamlarının öğrenci başarısına ve görüşlerine etkisi. Turkish Journal of Educational Studies, 2(2), 75-102.

Akınoğlu, 0. (2017). Pre-service teachers' metaphorical perceptions regarding the concept of curriculum. International Journal of Instruction, 10(2), 263-278.

Aktepe, V. (2005). Eğitimde bireyi tanımanın önemi. Gazi Üniversitesi Kırșehir Eğitim Fakültesi Dergisi, $6(2), 15-24$.

Akbaba-Altun, S., \& Apaydın, Ç. (2013). Kız ve erkek öğretmen adaylarının "eğitim" kavramına ilişkin metaforik alglları. Kuram ve Uygulamada Eğitim Yönetimi [Educational Administration: Theory and Practice], 19(3), 329-354.

Arslan, M. M., \& Bayrakçı, M. (2006). Metaforik düşünme ve öğrenme yaklaşımının eğitim-öğretim açısından incelenmesi. Milli Ĕgitim, 171, 100-108.

Aslan, S. (2013). Birleştirilmiş sınıflarda görev yapan öğretmenlerin "öğretmen” kavramı ile ilgili algılarının metaforik incelenmesi. Turkish Studies, 8(6), 43-59.

Aubusson, P. J., Harrison, A. G. \& Ritchie, S. M. (2006). Metaphor and analogy Metaphor and analogy in science education (pp. 1-9): Springer.

Aydın, İ. S., \& Pehlivan, A. (2010). Türkçe öğretmeni adaylarının öğretmen ve öğrenci kavramlarına ilişskin kullandıkları metaforlar. Turkish Studies, 5(3), 818-842. 
Botha, E. (2009). Why metaphor matters in education. South African Journal of Education, 29, 431-444.

Brown, T. (2018). Lifelong learning: An organising principle for reform. Australian Journal of Adult Learning, 58(3), 312-335.

Buchanan, J. (2015). Metaphors as two-way mirrors: Illuminating pre-service to in-service teacher identity development. Australian Journal of Teacher Education, 40(10), 33-50.

Büyüköztürk, Ş., Çakmak, E. K., Akgün, Ö. E., Karadeniz, Ş., \& Demirel, F. (2013). Bilimsel araştırma yöntemleri (15. Baskı). Ankara: Pegem Akademi.

Cerit, Y. (2010). Öğrenci, öğretmen ve yöneticilerin müdür kavramı ile ilgili metaforlara ilişkin görüşleri. Eğitim ve Bilim, 33(147), 3-13.

Çelikkaya, H. (1990). Eğitim olgusunun özellikleri. Marmara Üniversitesi Atatürk Eğitim Fakültesi Eğitim Bilimleri Dergisi, (2), 67-72.

Çelikten, M., Şanal, M., \& Yeni, Y. (2005). Öğretmenlik mesleği ve özellikleri. Erciyes Üniversitesi Sosyal Bilimler Enstitüsü Dergisi, 1(19), 207-237.

Çocuk, H. E., Yokuş, G., \& Tanrıseven, I. (2015). Pedagojik formasyon öğrencilerinin öğretmenliğe ilişkin öz-yeterlik ve metaforik alglları: Mersin Üniversitesi örneği. Mustafa Kemal Üniversitesi Sosyal Bilimler Enstitüsü Dergisi, 12(32), 373-387.

Çolakoğlu, M. (2005). Eğitim örgütlerinde değişim ve liderlik. HAYEF Journal of Education, 2(1), 63-77.

Döş, İ. (2011). Okul paydaşlarının metaforlar yardımıyla okul örgütlerini algılama biçimlerinin değerlendirilmesi. Doktora Tezi, Fırat Üniversitesi Sosyal Bilimler Enstitüsü, Elazı̆̆.

Ekiz, D. (2015). Bilimsel araştırma yöntemleri (4. Baskı). Ankara: Anı Yayıncılık.

Ekiz, D., \& Koçyiğit, Z. (2013). Sınıf öğretmenlerinin “öğretmen” kavramına ilişkin metaforlarının tespit edilmesi. Kastamonu Eğitim Dergisi, 21(2), 439-458.

Erden, H. (2016). Pre-service teachers' perceptions on being a teacher through a metaphoric perspective. The Anthropologist, 24(1), 134-147.

Gedikoğlu, T. (2005). Avrupa Birliği sürecinde Türk eğitim sistemi: Sorunlar ve çözüm önerileri. Mersin Üniversitesi Eğitim Fakültesi Dergisi, 1(1), 66-80.

Goldstein, L. S. (2005). Becoming a teacher as a hero's journey: using metaphor in preservice teacher education. Teacher Education Quarterly, 32(1), 7-24.

Güven, M., Yıldırım, E., \& Çelen, G. (2015). Yaşam boyu öğrenme kavramına ilişkin kullanılan metaforlar. Uluslararası Eğitim Programları ve Öğretim Çalışmaları Dergisi, 5(9), 35-47.

Haskins, R. (1989). Beyond metaphor: The efficacy of early childhood education. American Psychologist, 44(2), 274-282.

Jensen, D. (2006). Metaphors as a bridge to understanding educational and social contexts. International Journal of Qualitative Methods, 5(1), 36-54.

Johnson, G. C. (2001). Accounting for pre-service teachers' use of visual metaphors in narratives. Teacher Development, 5(1), 119-140.

Karaküçük, S. A. (2012). Excellent society-ideal education: educational models in the optimistic utopias. Journal of Education and Future, 1, 119-132.

Kasoutas, M., \& Malamitsa, K. (2009). Exploring Greek teachers' beliefs using metaphors. Australian Journal of Teacher Education, 34(2), 64-83.

Kıral, E. (2015). Öğretmen adaylarının algllarına göre öğretmen metaforları. Adnan Menderes Üniversitesi Eğitim Fakültesi Eğitim Bilimleri Dergisi, 6(1), 57-65.

Kim, M. S. (2012). Cultural-historical activity theory perspectives on constructing ICT-mediated metaphors of teaching and learning. European Journal of Teacher Education, 35(4), 435-448.

Kalem, S., \& Fer, S. (2003). Aktif öğrenme modeliyle oluşturulan öğrenme ortamının öğrenme, öğretme ve iletişim sürecine etkisi. Kuram ve Uygulamada Ĕ̆itim Bilimleri, 3(2), 433-461.

Koç, E. S. (2014). Sınıf öğretmeni adaylarının öğretmen ve öğretmenlik mesleği kavramlarına ilişkin metaforik algıları. İnönü Üniversitesi Ĕ̆itim Fakültesi Dergisi, 15(1), 47-72.

Konaklı, T., \& Göğüş, N. (2013). Metaphorical perceptions of pre-service teachers in related to faculty of education: A sample of Kocaeli University Faculty of Education. International Journal of Human Sciences, 10(2), 67-93.

Konopasky, A. W., \& Reybold, L. E. (2015). Accessing the world: Adult literacy educators' metaphors for learners and learning. Journal of Transformative Education, 13(3), 239-258.

Kucuk, M., \& Yalcin, Y. (2014). Turkish elementary school teacher candidates' technology metaphors. Turkish Journal of Teacher Education, 3(1), 53-63.

Kumral, O. (2017). Eğitimin toplumsal temelleri. Fatma Susar Kırmızı ve Nil Budan (Ed.), Eğitim Bilimine Giriş içinde (s. 115-135). Ankara: Anı Yayıncılık.

Kuyumcu, F. N., \& Özsarı, İ. (2016). 5. ve 6. sınıf öğrencilerinin öğretmen ve okul kavramlarına ilişkin algılarının değerlendirilmesi. Ĕ̆itim ve Öğretim Araştırmaları Dergisi, 5(44), 396-407. 
Liaquat, S., \& Naz, A. (2016). Analytical study of teacher educators' metaphors of teaching. Journal of Education and Educational Development, 3(1), 30-51.

Lakoff, G., \& Johnson, M. (2003). Metaphors we live by. Chicago: The University of Chicago Press. (Original work published 1980).

Mahlios, M. C. (2002). Teacher role formation. Action in Teacher Education, 24(1), 9-21.

Ministry of National Education. (1973). 1739 Sayılı Milli Eğitim Temel Kanunu. 24.6.1973 tarih ve 14574 sayılı Resmi Gazete.

Morgan, G. (1998). Images of organization: The executive edition. Thousand Oaks: SAGE Publication.

Mouraz, A., Pereira, A. V., \& Monteiro, R. (2013). The use of metaphors in the processes of teaching and learning in higher education. International Online Journal of Education Sciences, 5(1), 99-110.

Nalçacı, A., \& Bektaş, F. (2012). Öğretmen adaylarının okul kavramına ilişkin algıları. Ahi Evran Üniversitesi Kırşehir Eğitim Fakültesi Dergisi, 13(1), 239-258.

Nikitina, L., \& Furuoka, F. (2008). Measuring metaphors: A factor analysis of students' conceptions of language teachers. Metaphorik.de, 15, 161-180.

Noyes, A. (2006). Using metaphor in mathematics teacher preparation. Teaching and Teacher Education, 22(7), 898-909.

Ogurlu, Ü., Öpengin, E., \& Hızlı, E. (2015). Üstün yetenekli öğrencilerin okul ve öğretmene ilişkin metaforik algıları. Dumlupınar Üniversitesi Sosyal Bilimler Dergisi, 46, 67-83.

Örücü, D. (2014). Öğretmen adaylarının okul, okul yönetimi ve Türk eğitim sistemine yönelik metaforik algıları. Kuram ve Uygulamada Ĕ̆itim Yönetimi Dergisi, 20(3), 327-358.

Özdemir, S., \& Akkaya, E. (2013). Genel lise öğrenci ve öğretmenlerinin okul ve ideal okul algılarının metafor yoluyla analizi. Kuram ve Uygulamada Eğitim Yönetimi, 2(2), 295-322.

Özden, M. (2018). Türkçe eğitimi lisans öğrencilerinin hazırlıklı ve hazırlıksız konuşma hakkında geliştirdikleri metaforlar. ODÜ Sosyal Bilimler Araștırmaları Dergisi (ODÜSOBİAD), 8(2), 347-357.

Patton, M. Q. (2014). Nitel araştırma ve değerlendirme yöntemleri (Çev. Ed. M. Bütün ve S. B. Demir). Ankara: Pegem Akademi.

Peculea, L. (2017). Investigation of future teachers' perceptions on education, teacher and teaching through metaphor analysis. Educatia 21 Journal, 15, 62-69.

Pektaş, M., \& Kıldan, A. O. (2009). Farklı branşlardaki öğretmen adaylarının “öğretmen” kavramı ile ilgili geliștirdikleri metaforların karşılaştırılması. Erzincan Üniversitesi Eğitim Fakültesi Dergisi, 11(2), 271-287.

Polatcan, M., \& Kılınç, A. Ç. (2018). Fenomenoloji ve araştırmalarda fenomenolojik yöntem. Kadir Beycioğlu, Niyazi Özer ve Yaşar Kondakçı (Ed.), Eğitim Yönetiminde Araștırma içinde (s. 391-408). Ankara: Pegem Akademi.

Renz, L. M. (2009). Metaphor: Imagery devices used by Morgan to describe organizations as culture and psychic prisons. Emerging Leadership Journey, 2(1), 54-65.

Saban, A. (2004). Giriş düzeyindeki sınıf öğretmeni adaylarının "öğretmen" kavramına ilişkin ileri sürdükleri metaforlar. Türk Eğitim Bilimleri Dergisi, 2(2), 131-155.

Saban, A. (2008). Okula ilişkin metaforlar. Kuram ve Uygulamada Eğitim Yönetimi Dergisi, 55, 459-496.

Şahin, A. \& Sabancl, A. (2018). The perception of pedagogical formation students have towards educational concepts: Metaphoric study. Journal of Education and Future, 13, 179-207.

Şişman, M. (2018). Eğitime giriş (17. Baskı). Ankara: Pegem Akademi.

Tulunay Ateş, Ö. (2016). Öğrencilerin öğretmen ve okul metaforları. International Journal of Contemporary Educational Studies, 2(1), 78-93.

Turan, M., Yıldırım, E., \& Tıkman, F. (2016). Öğretmen adaylarının eğitim ve bazı temel kavramlara ilişskin metaforik algları. Education Sciences, 11(4), 217-242.

Vadeboncoeur, J. A., \& Torres, M. N. (2003). Constructing and reconstructing teaching roles: A focus on generative metaphors and dichotomies. Discourse: Studies in the Cultural Politics of Education, 24(1), 87-103.

Yıldırım, A. \& Şimşek, H. (2016). Sosyal bilimlerde nitel araştırma yöntemleri (10. Baskı). Ankara: Seçkin.

Yıldızlı, H., Erdol, T. A., Baştuğ, M., \& Bayram, K. (2018). Türkiye'de öğretmen kavramı üzerine yapılan metafor araştırmalarına yönelik bir meta-sentez çalışması. Eğitim ve Bilim, 43(193), 1-43. 